\title{
The Impact of The Negative Effects of Integration on the Competitiveness of the Russian Economy in the Context of Functioning of the Customs Union
}

\author{
Sergei Vladimirovich Shkiotov \\ Marina Alexandrovna Ugryumova \\ Marina Arkadevna Mayorova
}

Yaroslavl State Technical University

Doi:10.5901/mjss.2015.v6n5s3p225

\begin{abstract}
The article analyzes the effects arising from functioning of the Customs Union and providing negative influence on the competitiveness of the Russian economy. In addition to the classic negative effects of integration (the deviation of trade, reallocation of resources), the authors consider new risks due to the nature of the Customs Union: formation of the model of political bargaining, the mechanism of formation of the $\mathrm{CU}$ and the effect of negative feedback.
\end{abstract}

Keywords: Customs Union, national competitiveness, World Economic Forum, negative effects, integration.

\section{Introduction}

January 1, 2015 the Eurasian Economic Union (EEU), composed of four states (Russia, Kazakhstan, Belarus, Armenia) began its work. New integration association arose on the basis of the Customs Union of Russia, Belarus and Kazakhstan (CU) and Common Free Market Zone (CFMZ). On the one hand, we can't but mention the rapidity of occurrence of this Association, and, on the other, it can be regarded as a kind of summary of the integration processes in the post-Soviet space initiated by the establishment of the Commonwealth of Independent States (CIS) in 1991.

The EEU in its formation went through all the classic stages of integration: free trade zone (within the CIS); the Customs Union; common market (CES) and finally, the highest stage of integration is the Economic Union. Something that for a United Europe took almost half a century, EEU passed for 5 years (October 18, 2011 was signed the agreement on free market zone between the 8 countries of the $\mathrm{CIS}$, although de facto this mode emerged with the establishment of the CIS). However, the creation of Eurasian Economic Union have finalized the borders of post-Soviet integration: Moldova, Georgia, Ukraine formed a conditional block of "opponents", making the choice in favor of European integration; Kyrgyzstan and Tajikistan - reserve of growth of EEU; Azerbaijan, Turkmenistan, Uzbekistan remain neutral, balancing between the power centers in the East (China) and the West (EU).

The creation of a new integration Association can be regarded as the most significant economic event in the postSoviet space after the collapse. Indeed, Russia, Kazakhstan, Belorussia Armenia, on the territory which live about 180 million people, have nearly $84 \%$ of the economic potential of the former USSR. According to data for 2014, the combined GDP of the four countries is 2 trillion. \$, a total turnover of about 900 billion \$. (World Bank Database, http://data.world bank.org/country/)

It is clear that integration processes can't but have a profound impact on the national competitiveness of countries in the global economy. The problem is that until the crisis in the Euro zone, few took seriously the risks that arise when creating integration Association of the uneven power economies. It is necessary to understand that for the rousing speeches of the presidents of the united countries, the rosy expectations of the benefits of integration, the economic strength of the EEU are objective evidence of a negative dynamics of trade flows between the member states, the economic slowdown, devaluation of national currencies.

The question of how will affect on the competitiveness of the Russian economy its participation in the activities of the CU will become the research object of this article. Here we must make an important caveat, because key agreement of EEU (political, monetary, energy) will be accepted only by 2025, the core of this integration Union still remains CU, with established procedures, standards, regulatory framework and institutions. Moreover the activities of the EEU (less than half a year) does not allow to operate with significant accumulated macroeconomic statistics, that is why later in the article we'll be talking primarily about the CU. 


\section{Main Text}

The starting point of this study will perform "The Global Competitiveness Report 2014-15" World Economic Forum, providing an overview of the competitive advantages and disadvantages of the largest economy in the Customs UnionRussia.

Despite a considerable number of studies on cross-national comparative studies in the field of national competitiveness, to the forefront in discussions on this issue goes the report of World Economic Forum (WEF) "The Global Competitiveness Report", which has a number of advantages: first, the report is published annually and has huge accumulated evidence base with length in 35 years; secondly, the study, unlike his analogue IMD World Competitiveness Yearbook, is absolutely for free; thirdly, it has an inner logic, a wide range of the analyzed indicators (more than 100) and countries (144), takes into account the opinion of the local expert community.

WEF is an independent international non-profit organization established in 1971 (headquartered Geneva, Switzerland). Since 2005, the WEF for the analysis of competitiveness of economies uses Global Competitiveness Index $(\mathrm{GCl})$, which is based on a combination of publicly available statistical data (about 20,000 records from 144 countries) and the results of a global survey of companies executives (more than 12,000 respondents). WEF define competitiveness as the set of institutions,policies, and factors that determine the level ofproductivity of a country. (The Global Competitiveness Report 2014-2015, http://www3.weforum.org/docs/WEF_GlobalCompetitivenessReport_2014-15.pdf, p.4).

Among the many factors that determine the competitiveness of the national economy, the WEF experts have identified more than one hundred indicators that are combined in the 12 pillars of competitiveness: institutions, infrastructure, macroeconomic environment, health and primary education, higher education and training, goods market efficiency, labor market efficiency, financial market development, technological readiness, market size, business sophistication, innovation.

The Russian economy in 2014 has strengthened its position in the ranking of national competitiveness (2005-2006, 53 place; 2006-2007, 62; 2007-2008, 58; 2008-2009, 51; 2009-2010, 63; 2010-2011, 63; 2011-2012, 66; 2012-2013, 67; 2013-2014, 64), taking in the global benchmarking $53^{\text {rd }}$ position out of 144 economies in the world (The Global Competitiveness Report 14-15, http://www3.weforum.org/docs/WEF_GlobalCompetitivenessReport_2014-15.pdf, p. 320). The analysis of data presented in the WEF report (table. 1), shows that over the past year, the Russian economy managed to improve almost all pillars of competitiveness, with the exception of macro economic environment.

As the authors of the report notes: «The Russian Federation is placed at $53^{\text {rd }}$ position this year with some improvements related to the efficiency of goods markets (in particular domestic competition), ICT use, and business sophistication - although this arguably reflects some positive developments that took place before the Ukraine conflict started» (The Global Competitiveness Report 14-15, http://www3.weforum.org/docs/WEF_GlobalCompetitiveness Report_2014-2015.pdf, p.25).

Table 1 - Russia in global competitiveness report, 2013-15

\begin{tabular}{|l|c|c|c|}
\hline CGI Rank & $2013-14$ & $2014-15$ & Trend line \\
Subindex & 64 (out of 148) & 53 (out of 44) & \\
Basicrequirements: & & & \\
- Institutions & 47 & 44 & +3 \\
- Infrastructure & 121 & 97 & +24 \\
- Macroeconomicenvironment & 45 & 39 & +6 \\
- Healthandprimaryeducation & 19 & 31 & -12 \\
Efficiency enhancers: & 71 & 56 & +15 \\
- Higher education and training & 51 & 41 & +10 \\
- Goods market efficiency & 47 & 39 & $+\mathbf{8}$ \\
- Labor market efficiency & 126 & 99 & +27 \\
- $\quad$ Financial market development & 72 & 45 & +27 \\
- Technologicalreadiness & 121 & 110 & +11 \\
- Marketsize & 59 & 59 & 0 \\
Innovationandsophisticationfactors: & 7 & 7 & 0 \\
- Businesssophistication & 99 & 75 & +24 \\
- Innovation & 107 & 86 & +21 \\
\hline
\end{tabular}


Competitive weaknesses of the Russian economy are traditionally associated with weakness of institutions: property rights (120 place in ranking out of 144 economics), burden of government regulation (111 place), protection of minority shareholders' interests (118); the undevelopment of competition: effectiveness of anti-monopoly policy (102), prevalence of trade barriers (111), prevalence of foreign ownership (124), and also low technological readiness: availability of latest technologies (108), FDI and technology transfer (123) (The Global Competitiveness Report 14-15, http://www3.weforum. org/docs/WEF_GlobalCompetitivenessReport_2014-2015.pdf, p.320).

To competitive advantages of the Russian economy can be attributed: domestic market size index (7), foreign market size index (9), general government debt, \% GDP (10), tertiary education enrollment, gross \% (19), pay and productivity (24) and a number of other indicators (The Global Competitiveness Report 14-15, http://www3.weforum.org/ docs/WEF_GlobalCompetitivenessReport_2014-2015.pdf, p. 320).

A brief overview of the competitive advantages of the Russian economy (according to WEF experts) allows to aggregate them into three groups: 1) macroeconomic stability (such indicators as: domestic market size index (7), foreign market size index (9), general government debt, \% GDP (10)); 2) system of higher education (indicators: tertiary education enrollment, gross \% (19)); 3) infrastructure (a number of available airline seat km/week, millions (11), fixed broadband Internet subscriptions/100 pop.(43),quality of railroad infrastructure (26)).

Dedicated competitive advantages can be described as predominantly short-term, since they largely rely on government support, highly dependent on the price situation on world commodity markets. Anti-Russian sanctions along with unfavorable for the Russian economy situation in world commodity markets has led to the fact that in the first year after the events in Ukraine can be observed: the decline in real GDP, the consolidated budget deficit, increasing the size of state debt, a sharp reduction in consumer demand (market capacity), sequestering of support on high education. In fact, from the three groups of competitive advantages of the Russian economy - the first two, at the moment, are under serious foreign policy and economic pressure. Taking into account that Russia has no own production of elements of the ICT- infrastructure on the one hand, and, on the other, the anti-Russian sanctions can affect the technology sector of the economy, cutting off the access to the Western telecommunications technologies, the third group of competitive advantages is also under the risk.

Moreover, the competitive disadvantages of the Russian economy is largely caused by the weakness of the institutional environment, which regardless of country ownership is changing very slowly, and, therefore, it is possible to predict a significant reduction of the rating of national competitiveness this year (positions 10-15).

Describing the competitive advantages and disadvantages of the largest economy of the $\mathrm{CU}$, let's turn directly to the analysis of risks arising from the establishment and operation of integration association of countries.

In the economic literature this topic has been researched for quite long time. In 1950 Jacob Weiner in "The Customs Union Issue" disclosed not only positive but also negative effects of establishment of Customs Union (Viner Jacob, 1950). Moreover, some effects come into effect immediately after the establishment of the Customs Union and act in a short time interval (static effects of integration), while others only become apparent in the long-term perspective (dynamic effects of integration) (Figure 1).

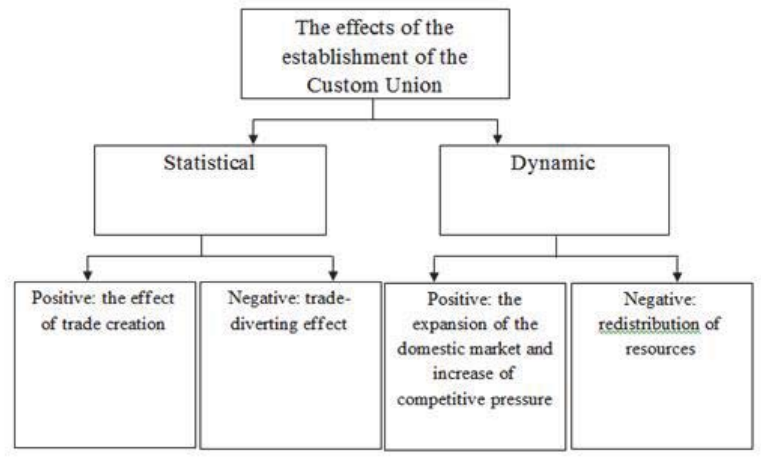

Figure 1 - The effects of establishment of the Customs Union

The overall impact of the Customs Union on the competitiveness of the economy is determined by comparing all of these effects. 
So, let's consider the negative effects of integration (static and dynamic) in the framework of under interest CU, creating risks for the competitiveness of the Russian economy:

1. The effect of trade diversion is the implementation of collective protectionism against third countries outside the Customs Union, and this effect is manifested in two ways, but in both cases negatively - on the one hand, through the reduction of welfare of the population, faced with the rising costs of imported goods, on the otherreduction of government revenues caused by economic inequality of participants of the Union. Let us discuss this effect in more detail. Firstly, since the creation of the CU based on the higher Russian customs duties, the Russians themselves, in fact, have not noticed a decrease in the level of well-being directly, but the residents of two other countries have fully experienced all the "charms" of dramatic appreciation of previously cheaper goods. For example, if prior to the entry of Kazahstan in CU the average level of import duties was $6.2 \%$, and with the formation of the Common Customs Tariff (CCT) the average level of import duties on goods for third countries was equal to 10.6\% (Rakhmatulina, 2012). Secondly, we are talking about reduction (shortfall) of income of the Russian budget at least due to two factors: reducing the tax deductions associated with the reregistration of Russian companies on the territory, first of all, Kazakhstan; incomplete transfer of customs duties to Customs Union partners. In practice this means that the cost effect of trade diversion is actually passed on to the leading economies of the CU - Russia, which pays for the possibility of its establishment and operation, and hence the Russians, indirectly but will face the problem of reducing the level of welfare through a decrease in the proportion of state spending to solve social and economic problems.

2. Effect of transfer of resources lies in the risks associated with suboptimal allocation of resources from poorer to richer economies. The context of the proposed unification is about labour migration from Kazakhstan and Belarus to Russia, i.e. the reallocation of labour force in the framework of the Customs Union in favor of countries with higher wage levels. For the Russian economy, this negative effect of integration by a more detailed consideration may be positive. On the one hand, the efficiency of the labor market in Kazakhstan, according to the WEF study, is higher than in Russia (advantages on such indicators as: flexibility of wage determination, hiring and firing practices, pay and productivity, country capacity to attract talent and etc.) (The Global Competitiveness Report 2014-2015. http://www3.weforum.org/docs/WEF_GlobalCompetitiveness Report_2014-15.pdf, p.231, 320). At the same time, taking into account the openness of borders for the movement of labor force and a significant advantage of Russia in the number of specialists with higher education (19th place ranking WEF 62 against Kazakhstan), and in Kazakhstan with secondary education (42nd 56 against Russia), raises the possibility of a gradual equalization of imbalances at the national labor markets (The Global Competitiveness Report 2014-2015. http://www3.weforum.org/docs/WEF_Global CompetitivenessReport_2014-15.pdf, p.231,320). On the other hand, labor migrants from Belorussia are considered by the population of Russia in general positively, but economic difficulties in neighboring economies release those resources that are needed in the Russian labor market - for example, builders, engineers, trades and unskilled laborer. In addition, we cannot forget about the classic costs-saving of production due to savings on the level of salaries of newly employed temporary workers.

These negative effects of integration, which have become classics in the Economics literature, are complemented with new risks associated with specific features of the internal contradictions of the CU (EEU). We are talking about: the forming of the model of political bargaining, mechanism of establishment of CU and the effect of negative feedback.

3. In our opinion, the mechanism of functioning of the $\mathrm{CU}$ in this moment is described by the model of political bargaining. This is evident not only in the opportunistic behavior of participants in the Customs Union in the context of the sanctions war against Russia when foreign-policy and economic constraints are used, for example, for re-export of prohibited products or as an opportunity to negotiate concessions from the largest economies of the Association. The idea is that any economic problems immediately transferred to the political plane and vice versa. Often, instead of the Eurasian Economic Union (EEU), designed to resolve all trade problems in a relationships partner countries, personal calls and negotiations of the presidents comes to the fore. This creates a pernicious practice, when instead consociational (compromise) model of decision making and dispute resolution in the framework of existing institutions, is arranged an alternative model of political bargaining.

Here are a number of factors that, in our opinion, have formed such a specific model of decision making within the CU.

A simple comparison of the economic potentials of the CU (see tab. 2) shows the enormous economic gap between the leading economy associations - Russia - and the other participants. The dilemma of "unequal union", 
however, typical of other integration associations, in the Russian realities acquires different, darker content: leading economic of integration union always pays the costs of its establishment and operation (preferences only to the Belarusian side for the 2000s, according to HSE estimates, amounted to $\$ 70$ billion.) (Ziyadullaev, 2014), however, economic inequality produces the famous temptation of political diktat, despite formally proclaimed principles of equality and taking into account of the national interests of the Parties. In this sense, noteworthy is statement of the President of Uzbekistan I. A. Karimov: "They say that create only economic market and in no way would abandon sovereignty and independence. Tell me, weather political independence is possiblewithout economic?" (Rotar, http://www.rosbalt.ru/ exussr/2014/06/17/1281144.html).

Table 2 - Main macrorconomic indicators of the countries-members of the CU, 2014 year. (The World Bank Database. http://data.worldbank.org/country/)

\begin{tabular}{|l|c|c|c|c|}
\hline Country & GDP (current US\$) & Population, total & GNI per capita, Atlas method (current US\$) & Inflation, consumerprices (annual \%) \\
Belarus & 76.14 & 9.47 & 7.340 & 18.1 \\
Kazakhstan & 212.2 & 17.29 & 11.670 & 6.7 \\
Russia & 1.861 & 143.8 & 13.210 & 7.8 \\
\hline
\end{tabular}

B. Strong authoritarian leaders, the lack of meaningful political competition. So, Polity IV (Polity, 2013) in his latest report clearly indicates the presence of authoritarianism (in its different variations) in all three countries of the CU. And, indeed, political leaders of Russia, Belarus and Kazakhstan have positions for three or more terms, what forms very specific patterns of behavior. And, if to remember that in these countries there is no real political competition as a mechanism of search of compromise in society, it is partly understandable the reluctance of heads of states (in the absence of a "habit") to make mutual concessions also at the resolution of trade disputes.

C. Institutional underdevelopment, the duration of formation of the dispute resolution procedures in the framework of the CU. The swiftness of the creation of the Customs Union in practice means not only lack of discipline in the execution of multiple rules of the Union, but, and most importantly, worked-out procedures for the resolution of disputes between participants of the integration Association. It is clear that such institutions, procedures of interaction are built slowly, and practice of work of new supranational authorities is far from being perfect. So, the Eurasian Economic Union (EEU), de jure as the institutional core of the CU, assumes not only the problem of formation of uniform rules, norms and procedures, but also the practice of settling disputes between countries of the Association. The problem is that, like any other supranational bureaucratic structure, the EEU is working slowly: dispute resolution is preceded by the procedure of establishment of conciliation commissions, exchange of documents, etc. This is in conflict with the informal practice of "telephone justice" of presidents, allowing not only to promptly resolve any disputes, by passing the established procedures and rules, but also to impose trade restrictions, often beyond the regulatory regime of the Customs Union. This creates not only reputational damage for the ECE, but also undermines the very basis of the functioning of this institution, turning it into a formally existing presidential authority to develop the regulatory framework, which, however, are poorly enforced.

Let's examine several cases revealing currently emerging practice in the resolution of trade disputes between countries of the Customs Union.

Formal (consociational) model of dispute resolution. In 2013 between the CU countries there was a dispute about the import from third countries of combine harvesters. This problem worsened after Russia's accession to the WTO, when duty on import of this technique has been severely reduced, and its import began to rise sharply.

The investigation carried out by the ECE due to sharply increased imports of combine harvesters on the territory of countries-members of the Customs Union, led to the decision to introduce in February 2013, the special protective duty at $27.5 \%$. As in Kazakhstan, there is no capacity to manufacture such equipments, this decision was very painful for the economy of the state. Kazakhstan has used its veto, and further, in accordance with prescribed in the contract and the regulations of the EEC procedures, September, the Prime Ministers of the countries of the Common Free Market Zone agreed upon the introduction of protective measures in the form of quotas on the import of combine harvesters on the market of the Customs Union, the total amount of 774 units per year with distribution among countries according to the historical principle (Ivanter, 2014). This case shows that the resolution of disputes between the countries of the Customs Union on the basis of compromise, in accordance with existing procedures and institutions is possible, and the EEC is a viable structure.

Informal model of political bargaining. In response to the conflict of the Belarusian side with the management of the Russian "Ur"|kaliy" in 2013, Russia was quick to introduce a number of trade restrictions on imports of dairy products from 
that country. In turn, the consent of Belarus on accession to the Eurasian Economic Union (EEU) was directly connected to A. Lukashenko with the question of the abolition of the transfer of export duties to the Russian budget from the export of petroleum products. The sharp devaluation of the ruble in late 2014, has made Russian goods more competitive on the markets of countries with a stable currency, that forced N. Nazarbayev through formal and informal channels to broadcast the idea of having to create a bulwark against Russian imports.

These and many other cases suggest that the model of political bargaining still remains the primary mechanism for the resolution of disputes within the Customs Union. Moreover: the current practice shows not only the weakness of the institutions of supranational regulation, procedures for the resolution of economic disputes, but also that short-term political benefits often outweigh the long-term economic interests.

2. The bases of the mechanism of establishment of the Customs Union (EEU) is not selective, but mechanistic principle for the inclusion of countries as part of the integration Association, which manifests itself in two ways:

A. the Lack of clearly defined mechanisms for the observance of macroeconomic, political, social requirements to the parameters of the economies of the countries members of the Customs Union (EEU) (common to all options: the deficit of consolidated budget of general government sector not above 3\% of GDP, the debt of this sector - not more than $50 \%$, the overall limit on inflation - the lowest level among all national economies, plus 5 percentage points) exacerbates the above dilemma of "unequal union". However, do not think that the $\mathrm{CU}$ is an exception to the rule, the expression "unequal Union" in the same measure applies to a United Europe. However, the difference in nuances between the $\mathrm{CU}$ and the EU is striking: the presence of clearly defined economic requirements for new members of the EU, common democratic principles, carefully designed procedures and initiatives have largely leveled, soften this problem. Moscow, in its turn, wants by all possible ways, regardless of socio-economic differences of the countries, to increase the number of participants, achieving greater economy scale, weight in the world economy, leaving the problem of aliasing disproportions for later. It can be said, that with the accession of the countries within the Customs Union is primarily because of geopolitical interests of one party, and in the case of the EU - economic of many. In this sense, demonstrative are the negotiations on accession to the Customs Union (EEU) of the poorest post-Soviet economies with unstable political regimes - Kyrgyzstan and Tajikistan.

B. Accession of Armenia (the Treaty of accession to the Union was signed on October 10, 2014) does not sharing common borders with the Customs Union (EEU), a well-known tension of country's relations with Azerbaijan are questioning the plans for the establishment of on the territory of integration Association of a powerful logistics hub connecting the East and West (Bikov, 2014, p. 32).

3. In the framework of integration associations there is an effect of negative feedback between countries, when the recession in the leading economy of the Union, as a liquid in communicating vessels flows (through the reduction of the volume of trade and production) in the less developed economies, dragging them behind it in a recessionary spiral. And in the opposite direction this effect, due to inequality of economies, does not act: the economic recession in the weaker economies will not have a significant impact on the Russian economy (Shkiotov, 2014).

\section{Conclusions}

Although the authors of the article have been allocated 5 negative effects (deviation of trade, reallocation of resources, the formation of models of political bargaining, the mechanism of formation of the $\mathrm{CU}$, the effect of negative feedback), which is related with the active participation of Russia in the operation of the $\mathrm{CU}$, to assess their impact on the competitiveness of the national economy is currently not possible for a number of reasons:

1. The terms of the existence of integration Association. The five-year period of operation of the CU and semiannual of EEU in practice means the incompleteness of the unification of procedures, regulations and rules, the transitional nature of the Association. Moreover, a proper analysis of the negative effects of the Customs Union is currently impossible and theoretically, as a part of them will occur only in the medium and long term perspective (dynamic effects) and at the moment to appreciate them for sure is not possible because of a lack of accumulated data.

2. The presence of exogenous factors. Price fluctuations on world commodity exchanges in 2014/15, antiRussian sanctions related to events in Ukraine, create additional negative pressure on the Russian economy. At the moment it is impossible to separate endogenous and exogenous factors, to assess their impact on the level of national competitiveness apparently.

3. Methodology for assessing competitiveness. In The Global Competitiveness Report (WEF) is missing such an important pillars of competitiveness as an Integration that does not let to take into account the influence of integration processes on the competitiveness of the national economy directly. In our opinion, in the globalized 
economy, the need to use such pillars, taking into account the impact of integration processes on the state of the economy has come to a head.

\section{Acknowledgment}

The reported study was partially supported by RFBR, research project No. 15-06-01820.

\section{References}

The World Bank Database. URL: http://data.worldbank.org/countryl.

The Global Competitiveness Report 2014-2015. URL: http://www3.weforum.org/docs/WEF_GlobalCompetitivenessReport_2014-15.pdf. Viner, Jacob (1950). The Customs Union Issue. New York: Carnegie Endowment for International Peace.

Rakhmatulina, G.G. (2012) The impact of the Customs Union on the economic development of Kazakhstan. Prospects for integration in the oil and gas sector. URL: http://www.eabr.org/general/upload/docs/publication/magazine/n01_2012/n1_2012_6.pdf.

Ziyadullaev, N. (2014) EEU: between politics and economy // Problems of theory and management practice. №11.

Rotar, I. Whether Rahmon will become Tajik Putin? URL: http://www.rosbalt.ru/exussr/2014/06/17/1281144.html.

Polity, I.V. (2013) Individual Country Regime Trends, 1946-2013. URL: http://www.systemicpeace.org/polity/polity4.htm.

Ivanter, A. (2014) "Gray areas" of the Customs Union - the result of subintegration // Expert. №4 (883).

Bikov, A. (2014) Eurasian integration, prospects and possibilities // Russian economic journal. №1.

Shkiotov, S.V. (2014) The Customs Union of Russia, Belarus and Kazakhstan: the theoretical aspect of the analysis // Economics and entrepreneurship. №5-2. 